\title{
A cellular protein that binds to the 5 '-noncoding region of poliovirus RNA: implications for internal translation initiation
}

\author{
Karen Meerovitch, ${ }^{1}$ Jerry Pelletier, ${ }^{3}$ and Nahum Sonenberg, ${ }^{1,2,4}$ \\ ${ }^{1}$ Department of Biochemistry and ${ }^{2}$ McGill Cancer Center, McGill University, Montréal, Canada H3G 1Y6
}

\begin{abstract}
Initiation of translation on poliovirus mRNA occurs by internal binding of ribosomes to a region within the 5'noncoding portion of the mRNA. The mechanistic details and trans-acting factors involved in this event are not understood fully. We used a mobility-shift electrophoresis assay to identify a specific RNA-protein complex, which can form between an RNA fragment that contains nucleotides 559-624 of the poliovirus 5' UTR (untranslated region) and a component or components of a HeLa cell extract. Complex formation was reduced greatly in a reticulocyte lysate or a wheat-germ extract. A 52-kD polypeptide (p52) has been identified as part of the protein-RNA complex by use of an UV cross-linking assay. This polypeptide apparently is not a known translation initiation or elongation factor. The possible involvement of p52 in translation initiation of poliovirus protein synthesis is discussed.
\end{abstract}

[Key Words: Translation; internal initiation; poliovirus; protein-RNA interactions]

Received January 25, 1989; revised version accepted April 11, 1989.

Poliovinus mRNA differs from most eukaryotic mRNAs in that it does not possess a $5^{\prime}$ cap structure $\left(\mathrm{m}^{7} \mathrm{GpppX}\right.$, where $\mathrm{X}$ is any nucleotide) (for reviews, see Shatkin 1976; Banerjee 1980). Instead, it contains a 5' pUp terminus (Hewlett et al. 1976; Nomoto et al. 1976). Recent in vivo and in vitro evidence has shown that ribosomes initiate translation on poliovirus mRNA by internal entry onto the $5^{\prime}$-noncoding region, without scanning from the $5^{\prime}$ end of the mRNA (Pelletier and Sonenberg 1988,1989 |. Similar evidence has been presented for another picornavirus, encephalomyocarditis virus (Jang et al. 1988).

The $5^{\prime}$-noncoding region of poliovirus mRNA contains (depending on the serotype) seven to eight AUG codons upstream of the initiator AUG. Mutational analysis of the seven upstream AUGs of poliovirus type 2 (Lansing strain) revealed that none of the AUGs, except for AUG-7, have any effect on virus replication (Pelletier et al. 1988c). A mutation in AUG-7 (an A $\rightarrow U$ substitution at position 588) resulted in a virus that had a small plaque phenotype, which indicated a positive role for the adenosine nucleotide of AUG-7 in poliovirus replication. Furthermore, Pelletier et al. (1988c) reported that in vitro-transcribed RNA, which contained the $5^{\prime}$-non-

\footnotetext{
${ }^{3}$ Current address: Massachusetts Institute of Technology Center for Cancer Research, Cambridge, Massachusetts 02139 USA.

${ }^{4}$ Corresponding author.
}

coding region of poliovirus with a mutation in $\mathrm{A}_{588}$, translated eightfold less efficiently than wild-type RNA in extracts from poliovirus-infected HeLa cells. It was suggested that $\mathrm{A}_{588}$ constitutes part of a motif that is important for translation initiation of poliovirus. This is consistent with the perfect conservation among picornaviruses of an octamer sequence that contains $\mathrm{A}_{588}$ (Kuge and Nomoto 1987; Rivera et al. 1988). This region can be folded into a stable stem-loop structure that is conserved among enteroviruses and rhinoviruses (Rivera et al. 1988). A sequence that spans nucleotides 567-627 of poliovirus type 1 (Mahoney strain) RNA has also been shown to be important for the translation of the viral mRNA in vitro (Bienkowska-Szewczyk and Ehrenfeld 1988). This region is part of a larger segment that is hundreds of nucleotides long and that is required for cap-independent translation of poliovirus RNA. It has been crudely delimited to nucleotides 320-631 and has been termed RLP for ribosome landing pad (Pelletier et al. 1988a; Pelletier and Sonenberg 1988) or region P for protein synthesis (Trono et al. 1988a,b).

On the basis of these reports, it is conceivable that ribosome binding could be facilitated by the action of trans-acting mRNA binding factors that confer specificity to the internal binding reaction. In this report, we describe the characterization of a $52-\mathrm{kD}$ polypeptide (p52) from HeLa cells that interacts specifically with the poliovirus 5 '-noncoding region that encompasses $A_{588}$. 


\section{Results}

To characterize better the cap-independent translation of poliovirus mRNA, we wished to identify putative trans-acting factors that may be involved in the mediation of this phenomenon. Since the region that encompasses $A_{588}$ (AUG-7) has been implicated in the cap-independent translation of poliovirus (Pelletier et al. 1988c), we wanted to study its interaction with proteins. RNA was transcribed from chemically synthesized oligodeoxynucleotides that contained the T7 promoter (Milligan et al. 1987). We used two constructs, one that generated wild-type RNA that contained 68 nucleotides termed A(559-624) and a second oligodeoxynucleotide that generated an RNA species that harbored a point mutation whereby $A_{588}$ was converted to $U_{588}$ termed U/559624). The oligodeoxynucleotide and the region within the poliovirus $5^{\prime}$ UTR to which the transcribed RNA corresponds are shown schematically in Figure 1.

\section{RNA-protein complex formation with A(559-624) RNA}

The RNAs produced by transcription with T7 RNA polymerase were purified by gel electrophoresis and used in a mobility-shift electrophoresis assay. HeLa cell S10 extracts were incubated with ${ }^{32} \mathrm{P}$-labeled A(559-624) RNA, treated with RNase T1, and analyzed on a lowionic-strength nondenaturing polyacrylamide gel. Formation of an RNA-protein complex was apparent (Fig. $2 \mathrm{~A}$, lane 1 , as compared to lane 11 without extract). A similar complex was detected if RNase T1 digestion was omitted, but a more pronounced background in the gel was noticed under these conditions (e.g., Figs. 3 and 4). When $\mathrm{T} 1$ digestion was used, we observed an enhance- ment of complex formation by several nucleotides. Addition of either hydrolyzable (GMP, GDP, and GTP; lanes 3-5) or nonhydrolyzable guanosine nucleoside phosphates (GMP-PCP; lane 7) stimulated complex formation (approximately fivefold). The addition of guanosine (lane 2) or the cap analog, $\mathrm{m}^{7} \mathrm{GDP}$ (lane 6) had little effect on complex formation, whereas ATP, CTP, and UTP (lanes 8-10) had some stimulatory effect on complex formation. Figure $2 \mathrm{~B}$ demonstrates the titration of GTP into the binding reaction. Optimal complex formation was achieved with $2 \mathrm{mM}$ GTP in the presence of 2 $\mathrm{mm} \mathrm{Mg}^{2+}$. These conditions were used in all further experiments. It is possible that the stimulatory effect of GTP and the other nucleotides was the result of their partial inhibition of RNase T1 activity (Irie 1964). Thus, addition of RNase Tl presumably caused some disruption of the specific complex in addition to elimination of nonspecific background.

\section{Specificity of complex formation}

To examine the RNA specificity for complex formation, we performed competition experiments with excess ${ }^{3} \mathrm{H}$ labeled A(559-624) RNA or a nonspecific competitor RNA that originated from the 5 '-noncoding region of human c-myc (nucleotides 69-224 with respect to the P1 transcription start site; Bernard et al. 1983). The results show that complex formation can be competed effectively with as little as a 20 molar excess of the specific A(559-624) RNA (Fig. 3, lane 2). Note that a complex that migrates slower than the major complex becomes apparent on competition and appears to be outcompeted less effectively than the major complex. A

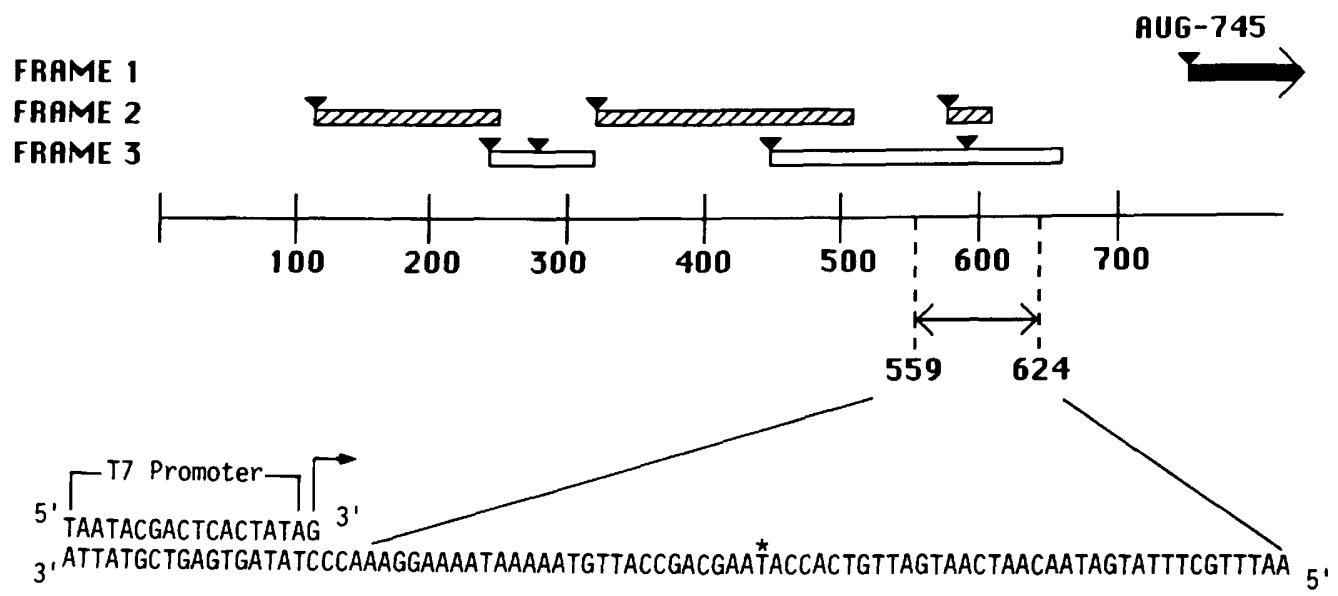

Figure 1. Schematic diagram of the $5^{\prime}$-noncoding region of poliovirus type 2 (Lansing strain). The small upstream ORFs in the 5 '-noncoding region are depicted by solid, hatched, and open rectangles. The upstream AUGs are represented by triangles. AUG-745 denotes the position of the initiator AUG for poliovirus polypeptide synthesis. The nucleotide sequence of the oligodeoxynucleotides used as template for T7 RNA polymerase transcription is also shown. The right-angle arrow denotes the start of transcription. The first three G nucleotides in the RNA are not part of poliovirus $5^{\prime}$ UTR, but were included to increase transcriptional efficiency (Milligan et al. 1987). Asterisk ( ${ }^{*}$ ) above the $T$ denotes the position at which an adenosine was substituted for a thymidine to create the $\mathrm{U}_{588}$ mutant RNA-U(559-624). 
Figure 2. (A) Nucleotide requirement for complex formation with A(559-624) RNA fragment. Complex formation was carried out as described in Materials and methods. HeLa cell S10 extract $(48 \mu \mathrm{g})$ was incubated with $10,000 \mathrm{cpm}$ RNA $(14,000 \mathrm{cpm} / \mathrm{ng})$ for 10 min at $30^{\circ} \mathrm{C}$ and processed as described. (Lanes 11 and 12) RNA before and after RNAse Tl digestion, respectively, in the absence of extract. $(B)$ Titration of GTP into the protein-RNA binding reaction. GTP was added in the amounts indicated above the figure. The $\mathrm{Mg}(\mathrm{OAc})_{2}$ concentration was $2 \mathrm{mM}$.

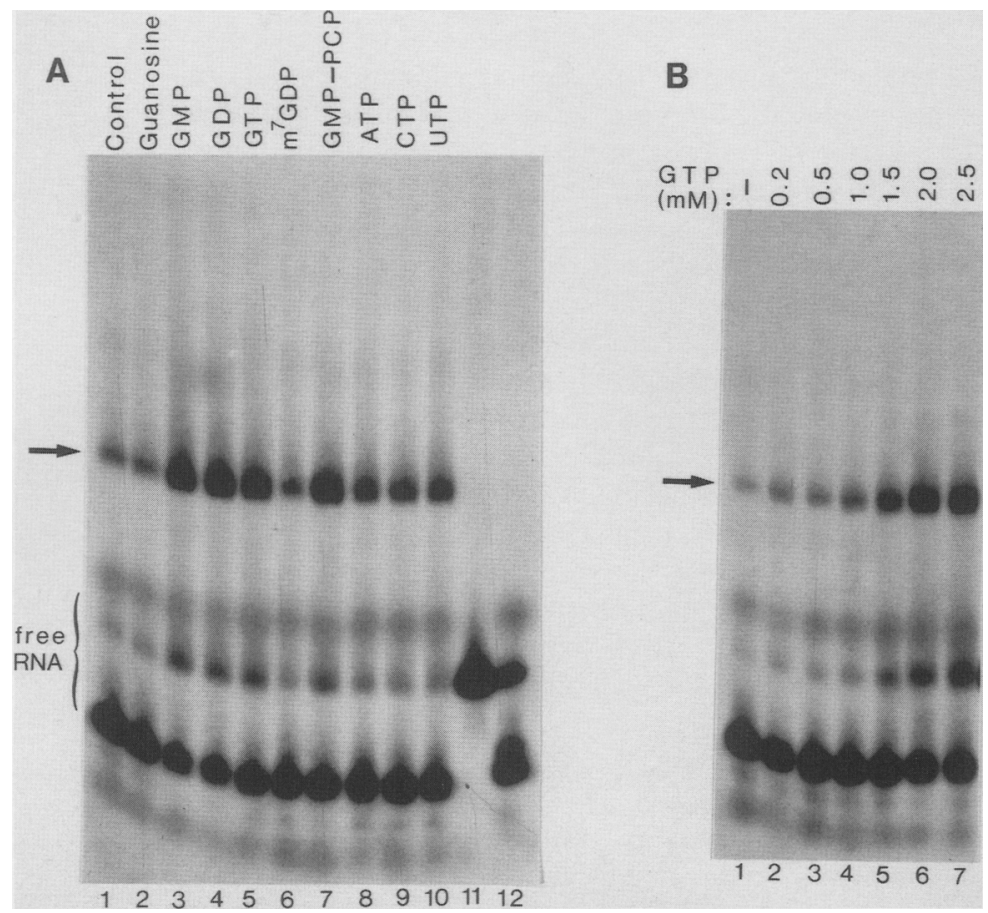

200-fold excess of the nonspecific c-myc RNA competitor had little effect on complex formation (lanes 5-7). In addition, other RNA species, including another poliovirus 5 '-UTR fragment that encompassed nucleotides 441-506, SP64 polylinker, and HIV-LTR did not compete for binding (data not shown).

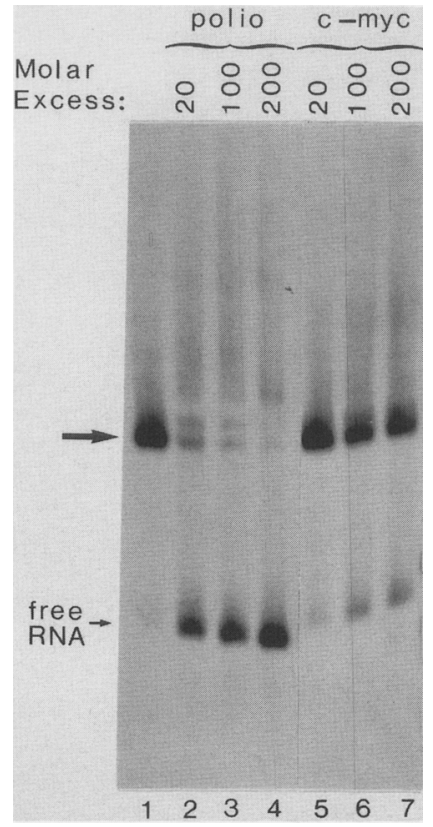

Figure 3. Specificity of complex formation. Complex formation was carried out as described in Materials and methods (except that RNase T1 digestion was omitted) in the presence of competitors in the preincubation step: ${ }^{3} \mathrm{H}$-labeled poliovirus RNA fragment, A(559-624) (lanes 2-4), or myc RNA (nucleotide 69-224) (lanes 5-7) was used (top).

\section{Complex formation with U(559-624) RNA}

The functional significance of complex formation with A(559-624) RNA was tested by comparison with the mutant U(559-624) RNA. Complex formation was performed with three different concentrations of $\mathrm{A}(559-$ 624) RNA (Fig. 4A, lanes 1-3). When the same concentrations of U(559-624) RNA were used, complexes were formed to a lesser degree (threefold) than with wild-type RNA (lanes 4-6). This result is consistent with the findings that the virus that contained this mutation replicated inefficiently and that translation of the mutated mRNA was impaired (Pelletier et al. 1988c). Thus, the complex observed by the mobility-shift electrophoresis assay is likely to reflect an early assembly step that precedes ribosome binding to poliovirus mRNA. (The migration of the complex is not consistent with that expected if it contained a $40 \mathrm{~S}$ ribosome: also see below where complex formation can occur with the S-100 fraction). To rule out the possibility that such a mobility shift could be obtained with any RNA that contained an AUG triplet, we performed the assay with a poliovirus RNA fragment encompassed nucleotides $441-506$ of poliovirus type 3 (Leon/37 strain), which contains two AUG codons. The results in Figure 4B show that this RNA did not form a complex with proteins in a HeLa cell extract.

Identification of proteins that cross-link to A(559-624) RNA

To identify the proteins that interact with $\mathrm{A}(559-624)$ RNA, ${ }^{32}$-labeled RNA was incubated with HeLa cell S10 extract and then irradiated with UV light. This re- 

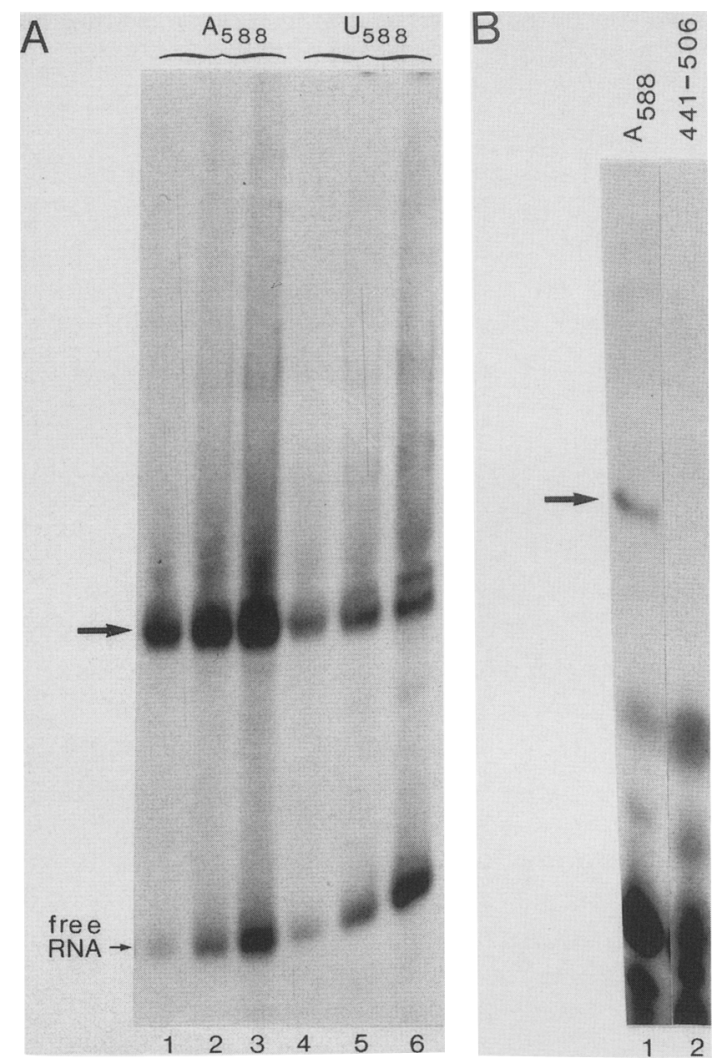

Figure 4. $(A)$ Comparison of complex formation between A $(559-624)$ and U(559-624) RNAs. Complex formation with ${ }^{32} \mathrm{P}$-labeled RNA was carried out as described in Materials and methods in the absence of RNase T1 digestion. (Lanes 1-3) $5,000,10,000$, and $20,000 \mathrm{cpm}$ of A(559-624)RNA denoted as $A_{588}$. (Lanes 4-6); 5,000,10,000, and 20,000 cpm of U(559-624) RNA denoted as $U_{588} \cdot(B)$ Complex formation did not result solely from the presence of AUGs. Complex formation with ${ }^{32}$ P-labeled A(559-624) RNA (lane 1) or ${ }^{32}$ P-labeled nucleotides 441-506 from poliovirus type 3 RNA (P3/Leon/37) (lane 2) was carried out as described in Materials and methods and was followed by RNase T1 digestion.

sulted in the cross-linking of one major polypeptide of $\sim 52 \mathrm{kD}$ and a minor polypeptide of $100 \mathrm{kD}$ (indicated by arrow; Fig. 5, lane 1). These polypeptides will be referred to throughout the text as p52 and p100, respectively. To assess the specificity of the cross-linking reaction, we performed incubations in the presence of excess ${ }^{3} \mathrm{H}-\mathrm{la}$ beled poliovirus A(559-624) RNA. Cross-linking of A(559-624) RNA in the presence of a 100-fold molar excess of A(559-624) RNA resulted in a significant reduction ( $\sim 50$-fold) of p52 cross-linking, whereas crosslinking of p100 was even increased ( $\sim 40$-fold, Fig. 5; cf. lane 2 to lane 1). These results suggest that the binding of p52 to A(559-624) RNA is specific, whereas that of p100 is not. This possibility is supported further by the cross-linking pattern obtained with mutated U(559624) RNA, which shows reduced cross-linking of p52 (2.5-fold), but increased (1.5-fold) labeling of p100, relative to the A(559-624) RNA (cf. lane 3 to lane 1). p52 is the polypeptide that binds specifically to A(559624) $R N A$

To determine whether p52 is present in the complex detected by the mobility-shift electrophoresis assay, we irradiated the reaction mixture that contained nucleoprotein complexes with UV light before or after analysis by the mobility-shift assay. Figure 6, lane 1, shows the cross-linking of $\mathrm{p} 52$ and $\mathrm{p} 100$ obtained by UV-irradiation in solution followed by SDS-PAGE analysis, as shown previously in Figure 5. Figure 6, lane 2, demonstrates the UV-cross-linked polypeptide that is associated with the nucleoprotein complex. Complexes were irradiated before mobility-shift electrophoresis analysis. The gel piece that contained the complex was excised and treated with nuclease, and the protein in the gel was subjected to electrophoresis on a SDS-polyacrylamide gel. Only p52 remained associated with the ${ }^{32} \mathrm{P}$-label after denaturing-gel analysis. Likewise, only p 52 was UV cross-linked when irradiation was performed after resolution of the nucleoprotein complex by the mobilityshift assay (lane 3). UV irradiation was necessary to label p52 because the identical procedure without UV irradiation did not result in p52 cross-linking (lane 4). These results indicate that $\mathrm{p} 52$ binds specifically to the poliovirus RNA 5' UTR that encompasses nucleotides $559-624$.

\section{p52 is not a known translation factor}

We considered the possibility that one of the known translation factors (initiation or elongation factors) might be p52. To examine this possibility, the mobilityshift electrophoresis assay was performed with purified

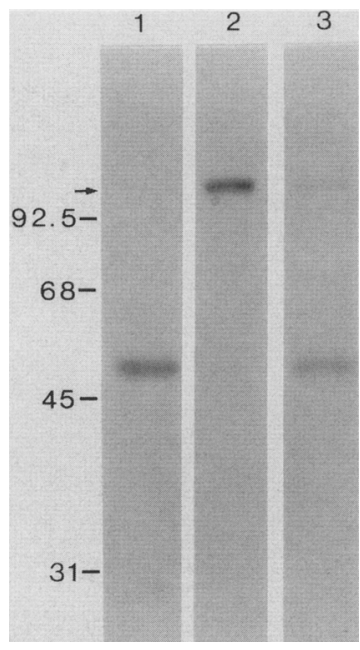

Figure 5. UV-induced cross-linking of HeLa cell S10 proteins to ${ }^{32}$ P-labeled RNA. ${ }^{32} \mathrm{P}$-Labeled A(559-624)RNA (lanes 1 and 2) or U(559-624) RNA (lane 3) was cross-linked to proteins in the HeLa cell $\mathrm{S} 10$ as described in Materials and methods. ${ }^{3} \mathrm{H}$ Labeled A(559-624) RNA (24 molar excess) was included in the preincubation step (lane 2). Samples were analyzed on a $10 \%$ SDS-PAGE and autoradiographed. Molecular masses in kilodaltons are shown on the left. 


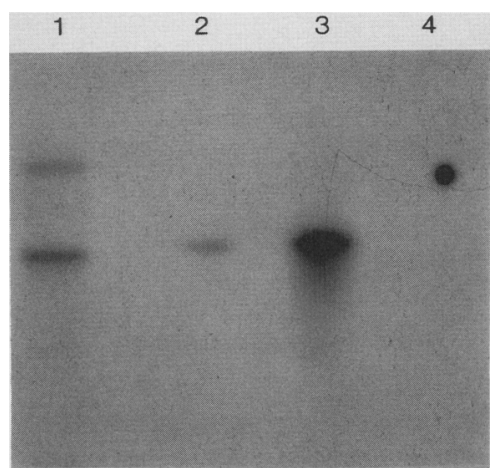

Figure 6. UV-induced cross-linking of proteins in the proteinRNA complex to ${ }^{32} \mathrm{P}$-labeled A(559-624) RNA. ${ }^{32} \mathrm{P}$-Labeled A(559-624) RNA was cross-linked to proteins in a HeLa cell S10 extract as described in Materials and methods (lane 1). ${ }^{32} \mathrm{P}$ Labeled A(559-624) RNA cross-linked to proteins in a HeLa cell S10 was subjected to mobility-shift gel electrophoresis, and the visualized complex was cut from the gel, treated as described in Materials and methods, and analyzed on a $10-15 \%$ SDS-polyacrylamide gel (lane 2). Alternatively, ${ }^{32}$ P-labeled A(559-624) RNA was incubated with HeLa cell S10 extract, and the nucleoprotein complex was resolved on a mobility-shift gel, UV-irradiated in situ, and then analyzed by SDS-PAGE (lane 3). Lane 4 is identical to lane 3 except that UV irradiation was omitted.

translation initiation and elongation factors. Several of the translation factors did not form complexes with A(559-624) RNA. These included initiation factors eIF-4A, eIF-4F, and elongation factors EF- $1 \alpha$ and EF-2 (data not shown). Four initiation factors eIF-2, eIF-4B, eIF-4D, and eIF-5, formed complexes with A(559-624) RNA. However, these complexes migrated in a manner different from that of the major nucleoprotein complex obtained with HeLa cell S10 extract (Fig. 7). Thus, none of the translation factors used here is similar to p52. Note that, although several purified initiation factors could form complexes with poliovirus RNA, no complexes of similar size formed in crude S10 extract (except for a weak complex that comigrated with the eIF-4BRNA complex; cf. lane 2 to lane 1). A possible explanation for this finding is that the affinity of p52 to Al559624) RNA is higher than that of other factors. Alternatively, it is possible that other factors, for example eIF-4B, cooperate in $\mathrm{p} 52$ binding to the RNA.

\section{Complex formation is inefficient in reticulocyte lysate and wheat-germ extract}

The region that encompasses $A_{588}$ is important for internal binding of ribosomes to the $5^{\prime}$-noncoding region (Pelletier et al. 1988a; Pelletier and Sonenberg 1988). Internal binding is efficient in HeLa cell extracts but not in a rabbit reticulocyte lysate (Pelletier and Sonenberg 1988). Likewise, translation of poliovirus RNA is efficient in HeLa cell extract, but inefficient in reticulocyte lysate (Shih et al. 1978; Pelletier et al. 1988b). The poliovirus RNA region that restricted translation in reticulo- cyte lysate was mapped to the $5^{\prime}$ half of the $5^{\prime}$-noncoding region and was found to also restrict translation in a wheat-germ extract and Xenopus oocytes (Pelletier et al. 1988b). Thus, it is conceivable that the latter extracts lack a factor implicated in internal binding. Therefore, it was of interest to examine the levels of p52-RNA complexes in rabbit reticulocyte lysate and wheat-germ extract. A mobility-shift electrophoresis assay was performed with extracts from HeLa cells, rabbit reticulocytes, and wheat germ. In this experiment we also examined the distribution of p52 between a postribosomal fraction and ribosomal fraction in HeLa cell extracts. Figure 8 (lane 1) shows complex formation in HeLa cell S10 extracts. Comparison between a postribosomal fraction (S100; lane 2) and a high-salt ribosomal wash fraction (RSW; lane 3) shows that most of the p52 is present in the postribosomal fraction. In reticulocyte lysate, a complex that migrated to a position similar to that of the HeLa cell complex was formed (lane 4). However, the amount of complex was considerably lower ( 10-fold) compared to that of the HeLa cell extract (cf. lane 4 to lane 1). Another complex that migrated slower could be seen in both HeLa cell S10 and reticulocyte lysate. This complex may have contained eIF-4B, as it comigrated with the eIF-4B-RNA complex (see Fig. 7). RNA-protein complex formation in the wheat-germ extract also was very inefficient (lane 5). These experi-

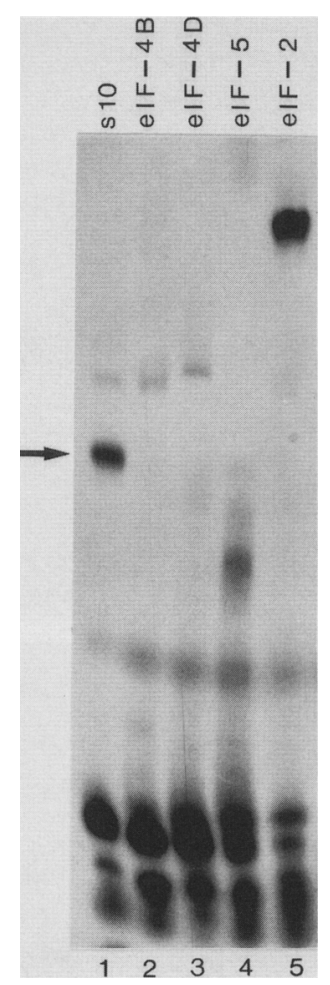

Figure 7. Mobility-shift electrophoresis assay of translation initiation factors. Initiation factors $(1-3 \mu \mathrm{g})$ were incubated with ${ }^{32} \mathrm{P}$-labeled $\mathrm{A}(559-624) \mathrm{RNA}$ at $30^{\circ} \mathrm{C}$ for $10 \mathrm{~min}$ in the absence of poly[d(I-C)]. Complex formation was as described in Materials and methods. 
ments were repeated with a wide range of concentrations of reticulocyte lysate and wheat-germ extract with similar results (data not shown). In addition, the mixing of HeLa cell S10 extract with wheat-germ and reticulocyte lysate did not cause inhibition of complex formation (data not shown). Thus, it appears that there are no inhibitors of complex formation in rabbit reticulocyte lysate and wheat-germ extract. These results are consistent with the notion that reticulocyte and wheat-germ extract are limiting in a factor required for internal binding of ribosomes to poliovirus mRNA.

\section{Discussion}

Previous results demonstrated that initiation of translation on poliovirus RNA occurs by internal binding of ribosomes to a region within the $5^{\prime}$-noncoding portion of the mRNA (Pelletier and Sonenberg 1988). The experiments described here were performed in an attempt to gain an understanding of the mechanism by which this occurs.

The boundaries of the structural element (nucleotides $559-624$ ) used in this study were chosen to keep the RNA fragment relatively small (to achieve a good mobility shift) and to encompass $A_{588}$. We also used an RNA fragment that encompassed nucleotides 320-631 of the poliovirus $5^{\prime}$ UTR and obtained a mobility shift with a HeLa cell S10 fraction. Preliminary experiments indicate that the RNA-protein complex formed with the 320-631 RNA fragment is larger than that formed with $\mathrm{A}(559-624)$ and may contain more than one protein (J. Pelletier, unpubl.). There are several observations that point to the region between nucleotides 559 and 624 of the poliovirus RNA as being an important determinant for translation initiation of poliovirus RNA. First, deletion of part of this region in poliovirus type 1 (Mahoney stain) yields virus with a small-plaque phenotype (Kuge and Nomoto 1987). Second, this region is part of a larger domain (from nucleotides 320 to 631) that is required for the cap-independent translation of poliovirus both in vivo and in vitro (Pelletier et al. 1988a; Pelletier and Sonenberg 1988, 1989; Trono et al. 1988b). Third, it was reported that in an in vitro translation system that consisted of a rabbit reticulocyte lysate supplemented by a HeLa cell extract, a 60 -nucleotide sequence from positions 567 to 627 in poliovirus type 1 (Mahoney strain) was important for efficient translation (Bienkowska-Szewczyk and Ehrenfeld 1988). Finally, the mutation of an $\mathrm{A}$ at position 588 of poliovirus type 2 (Lansing strain) caused a small-plaque phenotype and reduced translational efficiency in HeLa cell-free extracts in vitro (Pelletier et al. 1988c).

Previous reports (Pelletier et al. 1988c; Pelletier and Sonenberg 1988) have postulated the possible existence of a trans-acting factor for internal binding of ribosomes to poliovinus mRNA. The $52-\mathrm{kD}$ polypeptide identified in this report might be such a factor. This protein is present in limiting amounts in several translation systems such as rabbit reticulocyte lysate, wheat-germ extract (Fig. 8), and Xenopus oocyte extract (K. Meero-

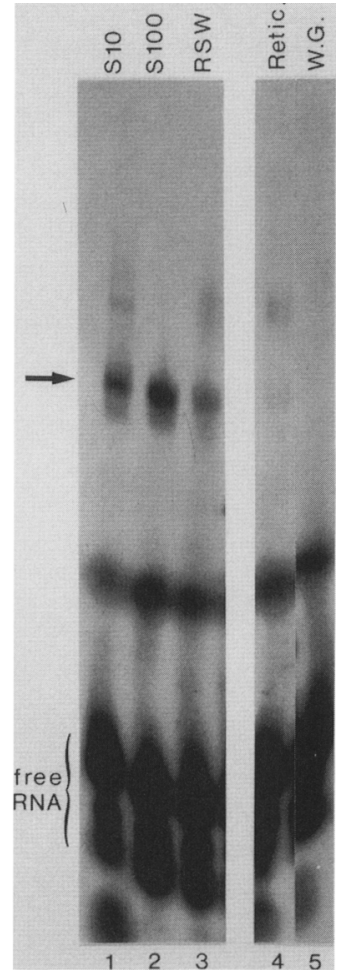

Figure 8. Comparison of complex formation between different extracts. Complex formation was carried out in the presence of ${ }^{32}$ P-labeled A(559-624) RNA with $40 \mu \mathrm{g}(2 \mu \mathrm{l})$ of HeLa S10 (lane 1), $20 \mu \mathrm{g}(2 \mu \mathrm{l})$ of HeLa S100 (lane 2), $10 \mu \mathrm{g}(0.2 \mu \mathrm{l})$ of HeLa ribosomal salt wash (RSW) (lane 3), $3 \mu$ l of rabbit reticulocyte lysate (lane 4$)$, or $140 \mu \mathrm{g}(2 \mu \mathrm{l})$ of wheat-germ extract (W.G., lane 5) and processed as described in the Materials and methods section. HeLa S10 extract was fractionated according to Lee and Sonenberg (1982). Rabbit reticulocyte lysate was obtained from Promega, and wheat-germ extract was prepared according to Roberts and Paterson (1973).

vitch, unpubl.l, but is present in greater amounts in HeLa cells (Figs. 1 and 8 ) and several other cell lines (HL-60, MOLT-4, and K562; unpubl.). Alternatively, it is possible that an additional factor required for p52 binding is present in HeLa cell extract, but limiting in other translation systems. These findings might explain the ability of mRNA that contains the 5' UTR of poliovirus RNA to translate efficiently in HeLa cell and L-cell extracts but not in reticulocyte lysate, wheat-germ extract, and Xenopus oocyte extract (Pelletier et al. 1988b). These findings have also engendered the suggestion that such a restriction of poliovirus translation might contribute in part to the tissue-specific replication of poliovirus (Pelletier et al. 1988b).

Translation of poliovirus RNA in a rabbit reticulocyte lysate long has been known to be inefficient (Shih et al. 1978), and a significant proportion of translation initiates in the P3 region located within the $3^{\prime}$ one-third of the RNA. The production of proteins from the $3^{\prime}$ onethird region of the genome, which is considered to be abnormal or aberrant, could be suppressed in favor of polyprotein synthesis from the $5^{\prime}$ end of the message by 
the addition of factors present in poliovirus-infected or uninfected cell extracts (Brown et al. 1979; Dorner et al. 1984; Phillips and Emmert 1986; Svitkin et al. 1988). The p52 identified here is likely to be equivalent to the initiation correcting factor (ICF) that was purified partially from Krebs-2 cells (Svitkin et al. 1988). This factor altered the selection of translation sites on poliovirus RNA in a rabbit reticulocyte lysate. It might also be significant that a major band in the ICF preparation is a 54- $\mathrm{kD}$ polypeptide that might correspond to the $\mathrm{p} 52 \mathrm{de}$ scribed in this paper (Svitkin et al. 1988). Because the ICF cofractionated with the eIF-2/eIF-2B complex, it was suggested by the authors that the ICF might be eIF-2/ eIF-2B complex. This is an interesting possibility, in light of the reported ability of eIF-2 to bind and to select the initiator AUGs of mengovirus and satellite tobacco necrosis virus RNAs for translation (Kaempfer et al. 1981; Perez-Bercoff and Kaempfer 1982). Moreover, the $\beta$ subunit of eIF-2 $(\sim 50 \mathrm{kD})$ has been cloned recently and shown to possess a zinc-finger motif, which is characteristic of several nucleic acid-binding proteins (Donahue et al. 1988; Pathak et al. 1988). However, the suggestion that eIF-2/eIF-2B is equivalent to ICF is not consistent with the findings that a reticulocyte ribosomal salt wash, rich in eIF-2/eIF-2B complex, and purified eIF-2/ eIF-2B complex by itself, had no ICF activity (Svitkin et al. 1988). Also, p52 is unlikely to be eIF-2 $\beta$, because $\mathrm{p} 52$ is present in very low levels in reticulocyte lysate or wheat-germ extract (Fig. 8), where eIF-2 $\beta$ is known to be present. Thus, our results demonstrate that p52 is unlikely to be a component of eIF-2, eIF-2B, or eIF-2/eIF-2B complex. Also, p52 is not a protein that binds to an AUG triplet in any RNA since another poliovirus RNA fragment that contained an AUG triplet did not form a similar complex with A(559-624) RNA (Fig. 4B).

Whether p52 recognizes a specific primary sequence domain, a secondary structure motif, or both, remains to be elucidated, but $\mathrm{p} 52$ could function by binding to the poliovirus mRNA template and could assist in the unwinding of local secondary structure by initiation factors eIF-4A and eIF-4B as suggested before (Pelletier and Sonenberg 1988). This would be a prerequisite for internal ribosome binding. Alternatively, one or multiple p52 molecules could bind to the mRNA template and transduce a signal for initiation factors and ribosome binding. An RNA component (aside from the mRNA template) is probably not involved in $\mathrm{p} 52$ binding because micrococcal nuclease treatment of the HeLa cell S10 extract prior to complex formation had no effect on the mobility or amount of complex formed (K. Meerovitch, unpubl.). Current studies are aimed at elucidating the mechanism by which p52 'primes' internal ribosome binding.

Internal ribosome binding has been reported to occur on several viral eukaryotic mRNAs other than those of picornaviruses (Herman 1986; Hassin et al. 1986). It is expected that $\mathrm{p} 52$ should function in these cases too. It is also conceivable that the machinery for internal ribosome binding in eukaryotes (including p52) exists for the translation of cellular mRNAs and not just for the benefit of viral mRNAs. Consistent with this notion we found that the level of complex formation is not changed in extracts from poliovirus-infected cells (K. Meerovitch, unpubl.). Previously, we have raised the possibility that cellular mRNAs that possess very long $5^{\prime}$-noncoding regions, some of which contain several small open reading frames (ORFs), might initiate translation by internal binding of ribosomes without scanning from the $5^{\prime}$ end of the message (Pelletier and Sonenberg 1988). This class of mRNAs consists of proto-oncogenes such as c-abl (Bernards et al. 1987) or c-jun (Ryder and Nathans 1988), homeo-box genes such as Drosophila Antennapedia (Stroehrer et al. 1986), and growth factors such as platelet-derived growth factor A chain (Betsholtz et al. 1986). Translation of mRNAs that occurs by internal ribosome binding could become prominent in mitosis when the activity of the cap binding protein is reduced (Bonneau and Sonenberg 1987). If indeed internal initiation is demonstrated to occur on these cellular mRNAs, then p52 might play a key role in the regulation of cellular development and differentiation.

\section{Materials and methods \\ Oligonucleotide templates}

Oligodeoxynucleotide templates for transcription by T7 RNA polymerase were synthesized on an Applied Biosystems DNA Synthesizer, gel-purified, eluted in $0.5 \mathrm{M}$ ammonium acetate overnight at $37^{\circ} \mathrm{C}$, and desalted by adsorption to a $\mathrm{Cl} 18$ reversephase SepPak mini-column. Annealing of oligodeoxynucleotides was carried out by heating equimolar amounts of the 18mer T7 primer oligodeoxynucleotide and the template oligodeoxynucleotide (see Fig. 1) to $100^{\circ} \mathrm{C}$ in $0.1 \mathrm{M} \mathrm{NaCl}$ and by slow cooling to room temperature.

\section{In vitro transcription}

T7 RNA polymerase was purified according to the procedure of Davanloo et al. (1984). Transcriptions by T7 RNA polymerase with oligodeoxynucleotide templates were carried out as described (Milligan et al. 1987), except that the nucleotide concentrations were $1 \mathrm{mM}$ for CTP, UTP, and ATP and $0.2 \mathrm{mM}$ for GTP. The $\mathrm{MgCl}_{2}$ concentration was $20 \mathrm{mM}$, and the DNA templates were used at a final concentration of $0.2 \mu \mathrm{M}$. Transcripts were labeled with $\left[\alpha-{ }^{32} \mathrm{P}\right] \mathrm{GTP}(3000 \mathrm{Ci} / \mathrm{mmole})$, gel-purified on $8 \%$ polyacrylamide $-8 \mathrm{M}$ urea gels, eluted, and recovered as described (Grabowski et al. 1984).

\section{Mobility-shift electrophoresis assay}

The mobility-shift electrophoresis assay was essentially as described by Konarska and Sharp (1986) with modifications by P. Sarnow (University of Colorado). Briefly, an S10 cytoplasmic extract ( $50 \mu \mathrm{g}$ protein) of HeLa cells, prepared as described (Lee and Sonenberg 1982), was preincubated with $1.25 \mathrm{mg} / \mathrm{ml}$ of poly[d(I-C)] (Pharmacia) in buffer that contained 5 mM HEPES (pH 7.6), $25 \mathrm{mM} \mathrm{KCl}, 2 \mathrm{mM} \mathrm{MgCl}, 3.8 \%$ glycerol, $0.02 \mathrm{~mm}$ dithiothreitol, and $1.5 \mathrm{~mm}$ ATP in a final volume of $10 \mu \mathrm{l}$ at $30^{\circ} \mathrm{C}$ for $10 \mathrm{~min}$. GTP was also included at a final concentration of $2 \mathrm{mM}$, except where indicated otherwise. For competition experiments, ${ }^{3} \mathrm{H}$-Labeled RNAs were included in the preincubation reaction. ${ }^{32} \mathrm{P}$-Labeled RNA $\left(10^{4} \mathrm{cpm}\right)$ was added and the mixture was incubated further at $30^{\circ} \mathrm{C}$ for $10 \mathrm{~min}$ to allow for 
complex formation. Samples were treated with RNase Tl 15 units, Boehringer-Mannheim) at $37^{\circ} \mathrm{C}$ for $15 \mathrm{~min}$, except where indicated otherwise. Glycerol was added to a final concentration of $10 \%$, and samples were loaded on a $5 \%$ polyacrylamide gel (39:1 acrylamide/bis-acrylamide) containing 5\% glycerol, which had been pre-electrophoresed for $30 \mathrm{~min}$ at 30 $\mathrm{mA}$. Electrophoresis was carried out at a constant current of 30 $\mathrm{mA}$ for $2.5 \mathrm{hr}$ at $4^{\circ} \mathrm{C}$ in $0.5 \times \mathrm{TBE}$. The gel was dried and exposed to X-ray film (Kodak) with intensifying screens at $-70^{\circ} \mathrm{C}$. Quantitations of complex formation were performed by scanning of X-ray films with an LKB soft laser densitometer.

\section{UV-induced cross-linking}

Cross-linking was performed essentially as described by Pelletier and Sonenberg (1985). Briefly, $5-10 \times 10^{4} \mathrm{cpm}$ of ${ }^{32} \mathrm{P}-\mathrm{la}-$ beled RNA were incubated with $100 \mu \mathrm{g}$ of S10 extract as described above, except that treatment with RNase T1 was omitted. Samples were irradiated with UV light from a germicidal lamp (254 nm) at a distance of $2-4 \mathrm{~cm}$ for $30 \mathrm{~min}$. Twenty micrograms of RNase A and 20 units of RNase Tl were then added, and the incubation continued at $37^{\circ} \mathrm{C}$ for $30 \mathrm{~min}$. Samples were analyzed by SDS-PAGE (Laemmli 1970) followed by autoradiography.

Analysis of the proteins complexed to RNA was performed according to a protocol provided by Dr. Mariano Garcia-Blanco (Cancer Research Center, MIT). After electrophoresis, the gel was irradiated with UV light for $30 \mathrm{~min}$, exposed to an X-ray film at $4^{\circ} \mathrm{C}$ for several hours, and the gel piece that contained the complex cut out. The gel slice was treated with a solution of $1 \mathrm{mg} / \mathrm{ml}$ RNase A in $0.5 \times \mathrm{TBE}$ at $37^{\circ} \mathrm{C}$ for $1 \mathrm{hr}$. The RNase solution was replaced by $2 \times$ SDS sample buffer and incubated further at $37^{\circ} \mathrm{C}$ for $30 \mathrm{~min}$, and then $65^{\circ} \mathrm{C}$ for $10 \mathrm{~min}$. The gel slice then was embedded in the stacking gel of an SDS-polyacrylamide gel and subjected to electrophoresis and autoradiography.

\section{Acknowledgments}

We thank Tom Dever, Bill Merrick, John Boal, and Brian Safer for translation initiation and elongation factors; Neil Parkin for c-myc RNA; and members of the laboratory and Isaac Edery for helpful comments on the manuscript. We are grateful to Mariano Garcia-Blanco for the protocol for cross-linked protein analysis. This research was supported by a grant from the Medical Research Council (MRC) of Canada. N.S. is a recipient of a Medical Council Research Scientist Award from the MRC of Canada, and K.M. is a recipient of a Cancer Research Society (Montreal) studentship.

\section{References}

Banerjee, A.K. 1980. 5'-Terminal cap structure in eukaryotic messenger ribonucleic acids. Microbiol. Rev. 44: 175-205.

Bernard, O., S. Cory, S. Gerondakis, E. Webb, and J.M. Adams. 1983. Sequence of the murine and human cellular myc oncogenes and two modes of myc transcription resulting from chromosome translocation in B lymphoid tumors. EMBO F. 2: 2375-2383.

Bernards, A., C.M. Rubin, C.A. Westbrook, M. Paskind, and D. Baltimore. 1987. The first intron in the human c-abl gene is at least 200 kilobases long and is a target for translocations in chronic myelogenous leukemia. Mol. Cell. Biol. 7: 32313236.
Betsholtz, C., A. Johnsson, C-H. Heldin, B. Westermark, P. Lind, M.S. Urdea, R. Eddy, T.B. Shows, K. Philpott, A.L. Mellor, T.J. Knott, and J. Scott. 1986. cDNA sequence and chromosomal localization of human platelet-derived growth factor A-chain and its expression in tumour cell lines. $\mathrm{Na}$ ture 320: 695-699.

Bienkowska-Szewczyk, K. and E. Ehrenfeld. 1988. An internal $5^{\prime}$-noncoding region required for translation of poliovirus RNA in vitro. $/$. Virol. 62: $3068-3072$.

Bonneau, A.-M. and N. Sonenberg. 1987. Involvement of the 24-kD cap-binding protein in regulation of protein synthesis in mitosis. J. Biol. Chem. 262: 11134-11139.

Brown, B.A. and E. Ehrenfeld. 1979. Translation of poliovirus RNA in vitro: Changes in cleavage pattern and initiation sites by ribosomal salt wash. Virology 97: 396-405.

Davanloo, P., A.H. Rosenberg, J.J. Dunn, and F.W. Studier. 1984. Cloning and expression of the gene for bacteriophage T7 RNA polymerase. Proc. Natl. Acad. Sci. 81: 2035-2039.

Donahue, T.F., A.M. Cigan, E.K. Pabich, and B.C. Valavicius 1988. Mutations at a $\mathrm{Zn}(\mathrm{II})$ finger motif in the yeast eIF-2 $\beta$ gene alter ribosomal start-site selection during the scanning process. Cell 54: 621-632.

Dorner, A.J., B.L. Semler, R.J. Jackson, R. Hanecak, E. Duprey, and $\mathrm{E}$. Wimmer. 1984. In vitro translation of poliovirus RNA: utilization of internal initiation sites in reticulocyte lysate. I. Virol. 50: 507-514.

Grabowski, P.J., R.A. Padgett, and P.A. Sharp. 1984. Messenger RNA splicing in vitro: an excised intervening sequence and potential intermediate. Cell 37:415-427.

Hassin, D., R. Korn, and M.S. Horwitz. 1986. A major internal intiation site for the in vitro translation of the adenovirus DNA polymerase. Virology 155: 214-224.

Herman, R.C. 1986. Internal initiation of translation on the vesicular stomatitis virus phosphoprotein mRNA yields a second protein. J. Virol. 58: 797-804.

Hewlett, M.J., J.K. Rose, and D. Baltimore. 1976. 5' terminal structure of poliovirus polyribosomal RNA is pUp. Proc. Natl. Acad. Sci. 73: 327-330.

Irie, M. 1964. Inhibition of ribonuclease $\mathrm{Tl}$ by various kinds of nucleotides. J. Biochem. 56: 495-497.

Jang, S.K., H.-G. Kräusslich, M.J.H. Nicklin, G.M. Duke, A.C. Palmenberg, and E. Wimmer. 1988. A segment of the $5^{\prime}$ non-translated region of encephalomyocarditis virus RNA directs internal entry of ribosomes during in vitro translation. J. Virol. 62: 2636-2643.

Kaempfer, R., J. Van Emmelo, and W. Fiers. 1981. Specific binding of eukaryotic initiation factor 2 to satellite tobacco necrosis virus RNA at a $5^{\prime}$-terminal sequence comprising the ribosome binding site. Proc. Natl. Acad. Sci. 78: 15421546.

Konarska, M.M. and P.A. Sharp. 1986. Electrophoretic separation of complexes involved in the splicing of precursors to mRNA. Cell 46: 845-855.

Kuge, S. and A. Nomoto. 1987. Construction of viable deletion and insertion mutants of the Sabin strain of type 1 poliovirus: function of the $5^{\prime}$ noncoding sequence in viral replication. J. Virol. 61: 1478-1487.

Laemmli, U.K. 1970. Cleavage of structural proteins during the assembly of the head of bacteriophage T4. Nature 227: $680-$ 685.

Lee, K.A.W. and N. Sonenberg. 1982. Inactivation of capbinding proteins accompanies the shut-off of host protein synthesis by poliovirus. Proc. Natl. Acad. Sci. 79: 34473451.

Milligan, J.F., D.R. Groebe, G.W. Witherell, and O.C. Uhlenbeck. 1987. Oligoribonucleotide synthesis using T7 RNA 


\section{Meerovitch et al.}

polymerase and synthetic DNA templates. Nucleic Acids Res. 15: 8783-8798.

Nomoto, A., Y.F. Lee, and E. Wimmer. 1976. The 5' end of poliovirus mRNA is not capped with $\mathrm{m}^{7} \mathrm{G}\left(5^{\prime}\right) \mathrm{ppp}\left(5^{\prime}\right) \mathrm{Np}$. Proc. Natl. Acad. Sci. 73: 375-380.

Pathak, V.K., P.J. Nielsen, H. Trachsel, and J.W.B. Hershey. 1988. Structure of the $\beta$ subunit of translational initiation factor eIF-2. Cell 54: 633-639.

Pelletier, J. and N. Sonenberg. 1985. Photochemical crosslinking of cap binding proteins to eucaryotic mRNAs. Effect of mRNA $5^{\prime}$ secondary structure. Mol. Cell. Biol. 5: 32223230.

Pelletier, J. and N. Sonenberg. 1988. Internal initiation of translation of eukaryotic mRNA directed by a sequence derived from poliovirus RNA. Nature 334: 320-325.

Pelletier, J., G. Kaplan, V.R. Racaniello, and N. Sonenberg. 1988a. Cap-independent translation of poliovirus mRNA is conferred by sequence elements within the 5 ' noncoding region. Mol. Cell. Biol. 8: 1103-1112.

Pelletier, J., G. Kaplan, V.R. Racaniello, and N. Sonenberg. 1988b. Translational efficiency of poliovirus mRNA: mapping of inhibitory cis-acting elements within the $5^{\prime}$ noncoding region. I. Virol. 62: 2219-2227.

Pelletier, J., M.E. Flynn, G. Kaplan, V.R. Racaniello, and N. Sonenberg. 1988c. Mutational analysis of upstream AUG codons of poliovirus RNA. J. Virol. 62:4486-4492.

Pelletier, J. and N. Sonenberg. 1989. Internal binding of eucaryotic ribosomes on poliovirus RNA: translation in HeLa cell extracts. I. Virol. 63: 441-444.

Perez-Bercoff, R. and R. Kaempfer. 1982. Genomic RNA of mengovirus: Recognition of common features by ribosomes and eukaryotic initiation factor 2. J. Virol. 41: 30-41.

Phillips, B.A. and A. Emmert. 1986. Modulation of the expression of poliovirus proteins in reticulocyte lysates. Virology 148: $255-267$.

Rivera, V.M., J.D. Welsh, and J.V. Maizel, Jr. 1988. Comparative sequence analysis of the $5^{\prime}$ noncoding region of enteroviruses and rhinoviruses. Virology 165: 42-50.

Roberts, B.E. and B.M. Paterson. 1973. Efficient translation of tobacco mosaic virus RNA and rabbit globin 9S RNA in cell-free system from commercial wheat-germ. Proc. Natl. Acad. Sci. 70: 2330-2334

Ryder, K. and D. Nathans. 1988. Induction of protooncogene c-jun by serum growth factors. Proc. Natl. Acad. Sci. 85: 8464-8467.

Shatkin, A.J. 1976. Capping of eucaryotic mRNAs. Cell 9: 645653.

Shih, D.S., C.T. Shih, O. Kew, M. Pallansch, R.R. Rueckert, and P. Kaesberg. 1978. Cell-free synthesis and processing of the proteins of poliovirus. Proc. Natl. Acad. Sci. 75: 5807-5811.

Stroehrer, V.L., E.M. Jorgensen, and R.L. Garber. 1986. Multiple transcripts from the antennapedia gene of Drosophila melanogaster. Mol. Cell. Biol. 6: 4667-4675.

Svitkin, Y.V., T.V. Pestova, S.V. Maslova, and V.I. Agol. 1988 Point mutations modify the response of poliovirus RNA to a translation initiation factor: a comparison of neurovirulent and attenuated strains. Virology 166: 394-404.

Trono, D., R. Andino, and D. Baltimore. 1988a. An RNA sequence of hundreds of nucleotides at the 5 ' end of poliovirus RNA is involved in allowing viral protein synthesis. $J$. Virol. 62: 2291-2299.

Trono, D., J. Pelletier, N. Sonenberg, and D. Baltimore. 1988b. Translation in mammalian cells of a gene linked to the poliovirus $5^{\prime}$ noncoding region. Science 241: 445-448. 


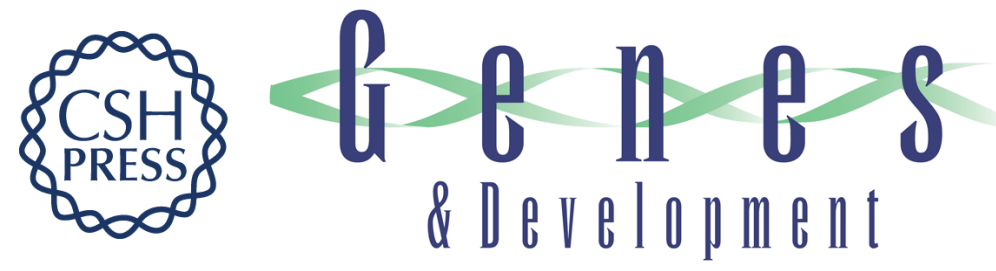

\section{A cellular protein that binds to the 5'-noncoding region of poliovirus RNA: implications for internal translation initiation.}

K Meerovitch, J Pelletier and N Sonenberg

Genes Dev. 1989, 3:

Access the most recent version at doi:10.1101/gad.3.7.1026

References This article cites 41 articles, 25 of which can be accessed free at:

http://genesdev.cshlp.org/content/3/7/1026.full.html\#ref-list-1

License

Email Alerting

Service

Receive free email alerts when new articles cite this article - sign up in the box at the top right corner of the article or click here.

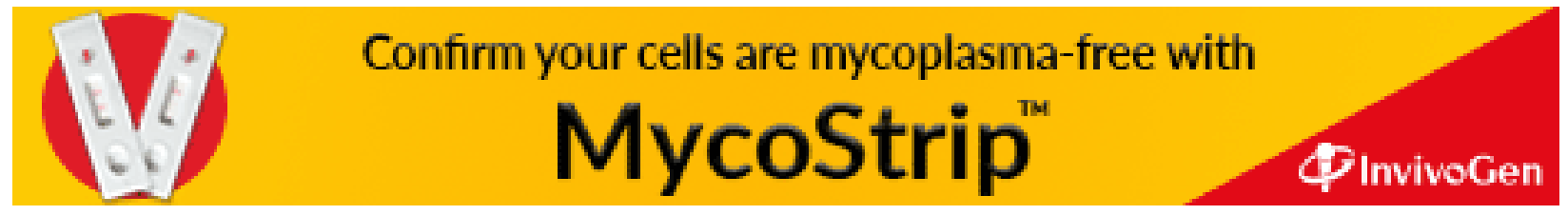

